\title{
Assessment of the Factors Causing Senior High Students Involvement in Examination Malpractice in the Takoradi Metropolis of Ghana
}

\author{
Abass Adamu1, Benjamin Blandful Cobbinah², Rukaya Alhassan ${ }^{3}$ \\ ${ }^{1}$ College of Teacher Education, Huzhou University, Huzhou, China \\ ${ }^{2}$ School of Economics and Management, Anhui University of Science and Technology, Huainan, China \\ ${ }^{3}$ Department of Accountancy, University for Development Studies, Tamale, Ghana \\ Email: adamuidrissou@gmail.com, bencobbah421@gmail.com, alhassanrukaya80@gmail.com
}

How to cite this paper: Adamu, A., Cobbinah, B. B., \& Alhassan, R. (2021). Assessment of the Factors Causing Senior High Students Involvement in Examination Malpractice in the Takoradi Metropolis of Ghana. Open Journal of Social Sciences, 9, 241-254.

https://doi.org/10.4236/jss.2021.96019

Received: May 18, 2021

Accepted: June 21, 2021

Published: June 24, 2021

Copyright ( 2021 by author(s) and Scientific Research Publishing Inc. This work is licensed under the Creative Commons Attribution International License (CC BY 4.0).

http://creativecommons.org/licenses/by/4.0/

(c) (i) Open Access

\begin{abstract}
Examination malpractice is a widely acknowledged syndrome in any educational system in the world all over. In Ghana, the level of students' involvement in examination malpractice in Senior High Schools in Ghana has become increasingly worrying, problematic and threatening to the well-being of Ghanaian educational system. The researcher adopted descriptive survey design in the context of this study. The general knowledge of this research is to bring out the various factors that contribute to the examination malpractice among senior high students in Takoradi Metropolis. The target population was 600 senior high students in the Metropolis across 35 schools registered under the Ghana Education Service. A simple random sampling technique was used to draw 500 students out of the total population by the researcher in which questionnaires were administered to the respondents. The data were analyzed using regression analysis to show the relationship that exists between the variables (student factor, teacher factor and environment factor) heading to examination malpractices. The results came out that, the student factor, teacher factor and environment factor all have a positive influence in bringing examination malpractices among senior high students in the Metropolis. The student factor contributed to $98.2 \%$ whereas both the teacher factor and environment factor contributed $95.5 \%$. The researcher recommended that, there should be intensified monitoring by the Ministry of Education through the help of standard officers and the head teachers to regulate examination malpractices. Also, it was recommended that, adequate spacing proper sitting arrangement of student helps to combat examination malpractice among senior high students in Takoradi Metropolis.
\end{abstract}




\section{Keywords}

Examination Malpractice, Takoradi Metropolis, Senior High Students (SHS), WAEC

\section{Introduction}

Education is an unavoidable component of every nation's socioeconomic growth, and Ghana is no exception. Since educational priorities and processes are guided by societal needs, aims, and desires, our young people receive a high-quality education that prepares them well to fit into society (Anane \& Asamoah-Gyimah, 2014). They highlight the importance of ensuring and achieving learning goals while teaching students, since learning results are completely realized after understanding the construct validity of one's educational achievement, as measured by grades. As a result, one of the procedures for determining one's educational achievement, which is measured by grades, is examination. In this instance, examination refers to the process of evaluating an examinee's output or actions by the use of a set of questions, issues, activities, or circumstances in order to determine the number, degree, or nature of information, capabilities, behaviors, or other attitudes that the person has obtained, the extent to which he or she is able to use them, or the consistency and effectiveness of the knowledge, skills, attitudes, or other behaviors that the individual has acquired (Azuru, 2009). Exam malpractice is as common as exams themselves. It is a global issue that affects not only Ghana, but the entire world, and it is already a central challenge (Yakubu, 1998).

According to Azuru (2009), examination malpractice is an unethical action taken by an examinee prior to, during, or after an examination mostly with the motive of acquiring an unfair advantage or receiving an unfair score. Exam malpractice is described by the WAEC (2003) as any suspicious activity shown by candidates or anyone entrusted with the responsibility of undertaking examinations both in and outside the exam room, before, during, or after the examination. Multiple kinds of individuals are involved in examination malpractice. Exam malpractice takes many forms, and it is getting more complex by the day. The occurrence of examination malpractice has been attributed to a variety of factors. These involve students' inability to connect with school activities, candidates' insufficient examination preparation, and candidates' willingness to pass exams at all times, and an overemphasis on paper qualifications (Adamu, 1998). According to Badejo and Gandonu (2010), the principle is a counter-practice that violates examination moral standards; this is an instance of disregard for all legal issues surrounding the moral behavior of any examination or evaluation method. Test malpractice is described in this study as any intentional act of misconduct by academic officials, students, or parents before, during, or after an exam to give oneself an advantage in the evaluation or the process of 
evaluation There are many factors that contribute to examination malpractice and there are many categories of people involved in examination malpractice in the Takoradi Metropolis. Any lasting solution to examination malpractice should, therefore, consider the categories of people involved and the factors contributing to its continuous occurrence.

According to Mulandu (2011), students presently engage in unethical conduct such as stealing, which appears to dominate their minds. Today's students strive for academic excellence while ignoring the ethical righteousness that falls in line with academic success. He went on to say that the majority of students don't care how they get good grades; what matters most to them are the good enough grades they achieve at the close of the examination session. Other types of examination malpractice and irregularity have been recorded by WAEC, the most notable of which was conspiracy and aided cheating including teachers, invigilators, managers, and even school owners (WAEC, 2009). The study went on to argue that Ghana has another emerging type of examination malpractice, which includes school officials knowingly registering unqualified candidates. Exam malpractice has become such a thriving 4 industry that it is possible that there are examination fraud cabals making a killing by participating in the unholy act (Onuka, 2011). Examination malpractice has become commonplace among students across the globe, but it is particularly concerning among students in Takoradi Senior High Schools. While there have been countless debates on whether examinations should be eliminated from school activities, there is no other way to evaluate the success of both teachers' and students' teaching and learning. In this context, the aim of this research is to look into the existence and causes of examination malpractice in a few senior high schools in the Takoradi Metropolis.

\section{Literature Review}

In our educational context, a variety of meanings have been proposed by different scholars. Test, according to (Ammani, 2011), is the assessment of proficiency or expertise, abilities, verbally or in writing, and the evaluation of the adequacy of these properties possessed by candidates. This is the core upon which the entire educational system operates. In technical terms, it is an activity that violates the rules and procedures of a specific review body at a precise moment. It is not only unethical and unconstitutional, but it also damages the educational system's reputation (The Ghanaian Times, 2011). When examination malpractice occurs in Ghana, however, the validity and outcome are called into question. Exam malpractice is generally described as a criminal act that violates official examination laws in order to unfairly benefit or disadvantage a candidate (Wilayat, 2009: p. 2). Examination malpractice, according to Fasasi (2006), is described as "misconduct or improper practice by examinees or others before, during, or after any examination with the goal of obtaining excellent results through illegal means". From these two definitions, it can be concluded that examination malpractice is 
an unethical act because it encourages mediocrity in that students who succeed through such unorthodox methods may be rated equal to those who struggle on their own to excel. Exam malpractice is unethical, according to these two concepts, because it promotes mediocrity by allowing students who perform by such unconventional approaches to be scored on par with those who fail to excel on their own.

According to (Nwandiani, 2005), examination malpractice makes it impossible to place a positive statement on a person based on their success in a collection of questions, comments, or a series of tasks designed to determine how much of a desired attribute, ability, or expertise the individual possesses. Despite all previous efforts to contain the spread of this issue, its pervasive and devastating effects grow to be evident in the Ghanaian educational system, which has an effect on the country's survival and prosperity. According to the Chief Examiner's Report (2019), following the completion of proceedings into reports of examination malpractice discovered during the execution of the Basic Education Certificate Examination (BECE), 173 candidates had their test scores revoked for carrying foreign objects into the exam room; 19 candidates had their test results revoked for bringing foreign objects into the exam room. According to Afolabi (2010), international materials carried into halls include scribes, textbooks, pages of textbooks, current and previous examination question papers, and blank pieces of paper. Students have also been asked to bring in exhibits including handkerchiefs, shirts, waist clips, and currency notes with copious notes and photocopies of ready responses, according to Afolabi. Candidates have even been asked to write notes on their palms and thighs. Society-based factors such as high levels of immoral behavior, widespread corruption, tribalism, nepotism, and a scarcity of jobs available in the nation all lead to these wrongdoings.

\subsection{Student Factor and Examination Malpractice}

According to Sommers \& Satel (2005), the experience of brazen disregard for laws and regulations in education is just a reflection of the larger circumstance in society. On the subject of wrongdoing in the assessment process, Badejo and Gandonu (2010) announced that it has reached an unmanageable level and that it should be a cause of worry for all key players in the education sector, issuing a clarion call to all to make strenuous efforts to reduce the situation. In his analysis of the factors that predispose students in Lagos universities to exam malpractice and the implications for therapy, he discovered that $83.3 \%$ believe that coordination between students and teachers triggers examination malpractice. On the part of students, Badejo and Gandonu (2010) revealed that 79.2 percent of those polled admitted to cheating, implying that students are partially to blame for cheating because their attitude toward attending lectures isn't exactly stellar. A $9 \%$ increase in this statistic, giving us a rounded number of $88 \%$, showed that students are influenced to cheat in examinations by the focus and angry demand 
for certificates. In a related research, Adeyemi (2010) discovered that the core factors of exam cheating are connected to general indiscipline among students, which was shared by $97.3 \%$ of his survey respondents. The prevalence of cheating, according to Ruwa (1997), can be due to poor distribution, inadequate facilities, poor service conditions, fear of failure, and admission of unqualified candidates. Fayombo (2004) summarizes the psychological and sociological triggers found, but believes that dependence on qualifications or paper certificates is the most significant causal factor.

\subsection{Teacher Factor and Examination Malpractice}

According to Abayeh (1996), the poverty level of supporting workers is at an all-time high, and in order to better their situation, they would use nefarious strategies to supplement their inadequate salaries. Supporting this claim with facts and figures, he claimed that $90 \%$ of employees will disregard laid-down rules and engage in nefarious activities for a fee, while $10 \%$ will not be interested in naming a price and will instead swap sex with students.

In the view of Erakhumen (2006), quoted in Ogonor \& Badmus (2006), basic and second cycle teachers lack sufficient expertise in the disciplines they claim to teach since their trainers at the time lacked the knowledge and were not adequately motivated. Further, institutional heads have been criticized for their students' bad results. In order to save face and redeem their reputation, they resort to providing students with the required force to protect $\mathrm{p}$ their future $\mathrm{Ba}$ dejo and Gandonu (2010) found that 83.3 percent agreed that lecturers' low attendance in class encourages students to cheat in exams, with $62.5 \%$ supporting their colleagues. They also found that lecturers' harshness in marking script breeds aggressive behaviors in exams.

\subsection{Environment Factor and Examination Malpractice}

Many researchers have conducted their study that find out that the environment of which the examination takes place have an influence in bringing examination malpractice among senior High Schools in Takoradi Metropolis. Teaching method, pedagogical design execution, consistency, outcomes assessment, and resource provision, according to them, define the teaching-learning activities. Uwadiae (1997) in a study conducted revealed among many other factors that \% of the variance academic misconduct is determined by exam facilities, school results, and entire population of the class and the location of the school. According to (Roig \& Ballew, 1994; Genereux \& McLeod, 1995; Crown \& Spiller, 1998; Whitley, 1998) proposed that the climate or atmosphere provided by the teacher or tutor in the classroom or test setting may have a major relationship with cheating. As a result, the close seating nature of candidates, poor seating arrangements, and the location of examination centers in remote areas where thorough supervision is difficult all appear to contribute to examination malpractices among Takoradi Metropolis Senior High School students. 


\section{Methodology}

\subsection{Research Design}

Under this section, the researcher used a descriptive survey to bring out the efficiency and the effectiveness of this study. It was chosen because of its suitability in previous studies on the subject to uncover the realities of the phenomenon among students in Takoradi Metropolis at the time of the research in relation to examination malpractices in Ghana and beyond.

\subsection{Population and Sample}

Ngechu (2004) describes population as a well-defined or investigated category of individuals, resources, components, activities, and group of items. The study focused on the public senior high Schools in the Takoradi Metropolis. A total of 35 public senior High schools in Takoradi Metropolis are being verified by the Ghana education service. The researcher however, focused on 600 students from these 35 schools representing the total population of students. According to Bartlett, Kotrlik and Higgins (2001), a sample of 155 can be drawn from a total population of 600 which has been proven fit for a study by a researcher.

\subsection{Instrumentation and Data Collection}

Under this study, the researcher developed an instrument customized factors that leads to examination malpractice involving senior high school students in Takoradi Metropolis. The questionnaire was made up of two sections. Section A based on the respondent's demographic characteristics, while Section B based on closed-ended topics on a point scale ranging from strongly agree to strongly disagree. A pre-test was done to measure the coefficient of the reliability; an index of 0.90 was obtained after Pearson product moment correlation was computed. Data was however collected by administration of questionnaire to the various respondents. Respondents were also assured of anonymity and confidentiality, as well as the option to opt out of the study if they so desired. 500 questionnaires were administered randomly for purpose of generalization across the 35 public senior high schools in the Metropolis.

\subsection{Data Processing and Analysis}

The data was analyzed using a statistical package for social sciences (SPSS) to generate the regression tables necessary for our study. This SPSS was used to analyze the data derived from the respondents to bring out the result for accessing the factors of examination malpractice among Senior High Students in Takoradi Metropolis.

\subsection{Conceptual Framework}

Under this section, the researcher tends to look for the factors that contribute to examination malpractices among senior High students in Takoradi metropolis. This study depicts the relationship that exists among these factors leading to 
examination malpractice in Takoradi metropolis. The relationships among these variables are presented in visual format (Figure 1).

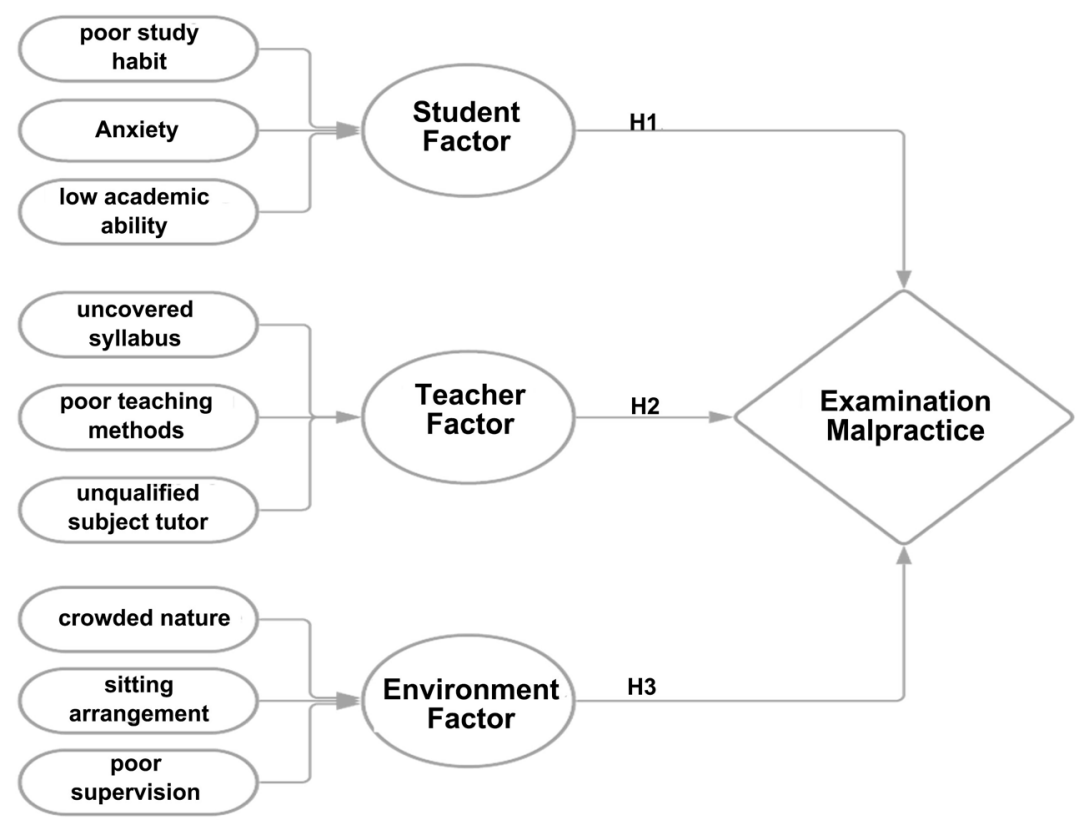

Figure 1. Conceptual framework.

\subsection{Research Hypothesis}

The researcher claims that student factor, teacher's factor and environmental factors all have a significant impact towards Senior High School student's engagement in examination malpractice in Takoradi Metropolis. It is however been hypothesized that:

\section{Hypothesis One}

$\mathrm{H}_{0}$ : There is no significant relationship between student factor and examination malpractice among senior high students in Takoradi Metropolis

$\mathrm{H}_{\mathrm{a}}$ : Student factor have a positive connection towards examination malpractice among Senior High Student in Takoradi Metropolis.

\section{Hypothesis Two}

$\mathrm{H}_{0}$ : There is no association or relation that exists between teacher factor and examination malpractice among Senior High Student in Takoradi Metropolis.

$\mathrm{H}_{\mathrm{a}}$ : The teacher factor is positively associated with examination malpractice among Senior High Student in Takoradi Metropolis.

\section{Hypothesis Three}

$\mathrm{H}_{0}$ : The environment factor does not have any positive influence in examination malpractice among Senior High Student in Takoradi Metropolis.

$\mathrm{H}_{\mathrm{a}}$ : Environmental factor positively influence examination malpractice among senior High Students in Takoradi Metropolis.

\section{Empirical Research}

Regarding this section of the study, an empirical analysis of the respondents was 
presented and discussed. The analysis begins by describing the sample distribution statistics of the survey respondents.

\subsection{Research Sample Distribution}

Statistics on Demographic Information of Respondents

Background information of respondents were collected by researchers covering areas such as gender, age and form of study of student-respondents. This information was collected in order to understand and give perspective to the response given by students in terms of their knowledge in the subject phenomenon under investigation. From the set of close-ended questionnaire given to student, an analysis of response on student's background revealed that a significant number the students were males (340) 68\% whiles their female counterparts were (160) in number also representing $32 \%$ of the total respondents that were involved in the study. Male students dominated the study due to their representation in the study compared to their female counterparts reflecting the bias nature the gender enrolment in senior high schools in the Takoradi Metropolis in Ghana. Information in Table 1 further revealed that (143) representing $28.6 \%$ of the total respondents were below the age of 12 years and just a few (19) $8 \%$ of them above 17 years. Majority of the respondents were between the age (12 and 16) with a total number of (338) $67.6 \%$ of the population. This implies that the students were old enough to give answers of their malpractice's habits in writing of WASSCE in Ghana. Regarding the form or level of study of students, it was found that (128) $25.6 \%$, (192) $38.4 \%$ and (180) $26 \%$ of the respondents respectively were in the First, Second and Third Year. This has been clearly illustrated in Table 1.

\subsection{Regression Analysis of the Effect of Student Factors, Teacher Factors and Environmental Factors on Students involvement in Examination Malpractices}

This section deals with the discussion of the results based on the data collected from the field. The data is used to answer the three research hypothesis that

Table 1. Background information of respondents.

\begin{tabular}{ccc}
\hline Variable & Sub-scale & Frequency \% \\
\hline Gender & Male & $340(68)$ \\
& Female & $160(32)$ \\
Age & Below 12 years & $143(28.6)$ \\
& $12-16$ years & $338(67.6)$ \\
Form of Study & Above 17 years & $19(3.8)$ \\
& One & $128(25.6)$ \\
& Two & $192(38.4)$ \\
& Three & $180(36)$
\end{tabular}

Source: Field Data (2020). 
guided the study. Multiple regression specifically the stepwise-Multiple regression was used in student-factors, teacher-factors and environment-factors on senior high school students involvement in examination malpractices in the Takoradi Metropolis in Ghana. Information in Table 2 summarizes the results and analysis of data collected student's response to the questionnaire adopted for the study. Three models were tested to see if the model could predict students' involvement in examination malpractices during the writing of WASSCE in the Takoradi Metropolis in Ghana. The study conducted some preliminary assumptions test on the data on student-factors, teacher-factors, environment-factors and students' involvement in malpractices before going ahead to run the regression analysis, needed in order. The test revealed a normal distributed data and with a linear association between dependent and independent variables.

\subsection{Model Estimation}

The researchers brought out the variables that influence examination malpractices among senior high school students in the Takoradi Metropolis of Ghana. The researchers identified the independent variables together with the dependent variables needed under this section for the study in a linear regression formula. Independent variables being student factor (SF), teacher factor (TF), and environment Factor (EF) whiles the dependent variable being examination malpractice (EMP) was developed in a simple regression which tends to show the relationship or the bond that exist between these variables.

Mathematically, the linear regression formula is being represented as

$$
Y=\beta_{0}+\beta_{1} X_{1}+\beta_{2} X_{2}+\beta_{3} X_{3}+\cdots+\beta_{n} X_{n}+\text { E. }
$$

However, the researcher decomposed $X_{1}, X_{2}$ and $X_{3}$ as SF, TF and EF respectively and $Y$ is EMP. By simple substitution, our model regression can be seen as:

$$
\mathrm{EMP}=\beta_{0}+\beta_{1} \mathrm{SF}+\beta_{2} \mathrm{TF}+\beta_{3} \mathrm{EF}+\mathrm{E}
$$

where: EMP $=$ Examination Malpractice, $\beta_{0}=$ Constant, $\mathrm{SF}=$ Student Factor, TF $=$ Teacher Factor, $\mathrm{EF}=$ Environment Factor and $\mathrm{E}=$ Error Term.

\subsection{Main Findings of the Study}

\begin{tabular}{|c|c|c|c|c|c|c|c|}
\hline & \multirow{2}{*}{ Model } & \multicolumn{2}{|c|}{ Unstandardized Coefficients } & \multirow{2}{*}{$\mathrm{T}$} & \multirow{2}{*}{ Sig } & \multicolumn{2}{|c|}{ Collinearity Statistics } \\
\hline & & B & Std. Error & & & Tolerance & VIF \\
\hline \multirow{2}{*}{1} & (Constant) & 0.013 & 0.133 & 0.096 & 0.923 & & \\
\hline & SF & 2.348 & 0.014 & 163.673 & 0.000 & 1.000 & 1.000 \\
\hline \multirow{3}{*}{2} & (Constant) & -0.859 & 0.077 & 11.102 & 0.000 & & \\
\hline & SF & 1.382 & 0.029 & 47.091 & 0.000 & 0.072 & 13.983 \\
\hline & $\mathrm{TF}$ & 0.345 & 0.010 & 34.160 & 0.000 & 0.072 & 13.983 \\
\hline \multirow{2}{*}{3} & (Constant) & -0.717 & 0.083 & -8.629 & 0.000 & & \\
\hline & SF & 1.570 & 0.053 & 29.726 & 0.000 & 0.021 & 46.818 \\
\hline
\end{tabular}

Table 2. Regression analysis of factors leading to senior high student (SHS) malpractices. 


\section{Continued}

\begin{tabular}{|c|c|c|c|c|c|c|}
\hline $\mathrm{TF}$ & 0.334 & 0.010 & 32.376 & 0.000 & 0.067 & 15.037 \\
\hline $\mathrm{EF}$ & -0.063 & 0.015 & -4.243 & 0.000 & 0.042 & 23.550 \\
\hline Model 1 & & Model 2 & & Model 3 & & \\
\hline $\mathrm{F}=6788.881$ & & $\mathrm{~F}=45,336.48$ & & $\mathrm{~F}=31,264.44$ & & \\
\hline $\mathrm{Df} 0=1$ & & $\mathrm{df}=2$ & & $\mathrm{df}=3$ & & \\
\hline$p=0.000$ & & $p=0.000$ & & $p=0.000$ & & \\
\hline $\mathrm{R}^{2}=0.982$ & & $\mathrm{R}^{2}=0.995$ & & $\mathrm{R}^{2}=0.995$ & & \\
\hline $\mathrm{R}^{2}$ Change $=0.982$ & & $\mathrm{R}^{2}$ Change $=0.013$ & & $\mathrm{R}^{2}$ Change $=0.000$ & & \\
\hline
\end{tabular}

Source: Field Data (2020).

\section{Model 1: EMP $=0.013+2.348$ SF + E Regressing Student-Factors on Examination Malpractices}

Based upon analysis of Information from Table 2, the study created a model to be tested in order to establish the fact that Student Factor predicted their involvement in examination malpractices in the Takoradi Metropolis. Model 1 was significant which indicates that there is significant effect of student-factors on examination malpractices, hence the researchers reject the null hypothesis that student-factor does not influence students' examination malpractices. This was revealed in a significance value $(p=0.000)$. From The analysis in Table 2 , It can be detected that student-factor (independent variable) has a positive and significant effect on the dependent variable (examination malpractices). This implies that an increment in student-factors such as lack of self-motivation, improper preparation towards exams, poor study habits and many more would significantly lead to a higher chance of student's examination malpractices. Hence, a $1 \%$ increase in student-factors such as those aforementioned would cause students involvement in malpractices by the coefficient (2.338). The $R$ square of Model 1 further proposes that student-factor explains $98.2 \%$ of students' involvement in examination malpractices. This signals the fact that there might be other plausible factors that accounts or predicts for student's involvement in examination malpractices, thus, justifying the need for model 2 to test to investigate the different aspects of independent variables that causes students involvement in examination malpractices.

Model 2: $\mathrm{EMP}=-0.859+1.382 \mathrm{SF}+0.345 \mathrm{TF}$ (Regressing Student-Factors and Teacher-Factors on Examination Malpractices)

Moreover, there was a need for a second model to test whether the combination of both student and teacher factors predicts student's involvement in examination malpractices. It was revealed that Model 2 is statistically significant ( $p$ $=0.000$ ), in predicting examination malpractices. This indicates that in addition to aforementioned student-factors, teachers teaching and learning habits such as preparing students for answering questions, inadequate preparation, poor teaching methods, inability to cover syllabus and many more also significantly causes students to be involved in examination malpractices. Model 2 further re- 
vealed the student-factors has a significant positive impact on students' involvement in examination malpractices by its coefficient (1.382). In addition, teacher-factors also appear to have a significant positive effect on students' involvement in examination malpractices by a coefficient value $(0.345)$. This surmises that a $1 \%$ increase in teachers factors such as those aforesaid would positively increase students' involvement in examination malpractices by its coefficient (0.345). The $\mathrm{R}$ square of model 2 insinuates that students' factors and teachers' factors explains $99.5 \%$ of variations in student's involvement in examination malpractices. It can be said that the introduction of the new variable (teacher-factors) contributed significantly. The teacher-factors alone explain this variation as a contribution to this model by $0.13 \%$. This implies that other factors explained the $0.05 \%$ of involvement in examination malpractices hence a need model 3 to fill in the gap that exists.

Model 3: $\mathrm{EMP}=-0.717+1.570 \mathrm{SF}+0.334 \mathrm{TF}+-0.063 \mathrm{EF}+\mathrm{E}$ (Regression Student Factors, Teacher Factors and Environment Factors on Examination Malpractices of Students)

The study finally proposed a final model to predict how student-factors, teacher-factors and environment-factors affect students' involvement in examination malpractices. The study found that independent variables such as student, teacher and environment factors significantly $(p=0.000)$ influence the dependent variable (examination malpractices). Both the student-factors and teacher-factors significantly and positively predicts student's involvement in examination malpractices while environment-factor such as location of examination enter, crowded nature of examination room and poor sitting arrangement significantly and negatively affect student's involvement in examination malpractices. The positive significance level of the student factor and teachers' factors implies that an increase in any of these factors would increase student's involvement in examination malpractices by respective coefficient of (1.570) and (0.334). However, a reduction in environment-factors revealed an increase in examination malpractice of students. Thus, a $1 \%$ increase in each of the two independent variables (student and teachers' factors) would influence students' involvement in examination malpractices by the coefficient (1.570) and (0.334) respectively. However, a $1 \%$ decrease in environment factor would also increase student's involvement in examination malpractices. The R square for Model 3 shows that $0.05 \%$ of the variation in students' involvement in examination malpractices is caused by student-factor, teacher-factors and environment-factors. There appears to be a connection between the findings revealed from this study and those done by scholars in the field of study. Studies conducted by (Adeyemi 2010; Badejo \& Gandonu, 2010; Erakhumen, 2006; Somers \& Satel, 2005; Roig \& Ballew, 1994; Genereux \& McLeod 1995; Crown \& Spiller, 1998; Whitley, 1998; Nwandiani, 2005). The remaining paragraph of the study concludes the study and offer recommendations of the need to improve upon some things in the teaching and learning classroom, environment so that examination malpractices 
in schools in the Takoradi Metropolis can be brought to the barest minimum.

\section{Conclusion and Recommendation}

\subsection{Conclusion}

Based on our findings of the study, it can be asserted that student factor, teacher factor and environment factor were the main factors that lead to examination malpractice among senior high students in the Takoradi Metropolis. It is observed from our findings that the student factor has the highest impact or influence of (98.2\%) that triggers examination malpractice among senior high students in Takoradi Metropolis. It is concluded that majority of student malpractice are initiated by the student themselves due to various reasons best known to them such as poor study habit, needs to avoid failure, anxiety and panic, and low academic ability. However, both teacher factor and environment factor such as unqualified teachers, inability to cover syllabus, poor teaching methods, poor sitting arrangement, and crowded nature of examination room and lack of subject knowledge by the teacher have the same value of impact (95.5\%) that leads to examination malpractice among the senior high students in the Metropolis.

\subsection{Recommendation}

Examination malpractices hinder the credibility and integrity of any examinations that are being conducted on students. Based on our findings, the researcher recommends that: The Ministry of Education through the standards officers and the head teachers should intensify monitoring of teaching and learning in order to ensure that teachers are doing their work and that there is quality delivery of lessons so as to develop confidence in students to enable them face the examinations. Security policies must be strengthened and enforced. This is possible if the company has a cheating policy that explicitly specifies which aids are permitted to be used on which types of exams and which are not. The policy must include directives regarding caught cheaters, as well as descriptions of the teachers' and proctors' roles in the event of a cheater bust. Teachers and proctors must be taught how to spot prohibited conduct. Students must also be mindful of this policy so that they are aware of all the implications of dishonesty.

Invigilators must be sufficient (1:30 candidates), strong and honest, and vigilant in their vigilance; installed cameras are helpful, but changing candidates' attitudes toward exams is even better. To discourage cheating, adequate spacing and seating arrangements are required. The rigidity and scheduling of exams should be checked in a way that if a student really cannot write an essay, another time appropriate for him should be scheduled. This will remove the fear of failure, which may lead to impersonation and other types of fraud.

\section{Conflicts of Interest}

No conflict of interest has been declared by the authors. 


\section{References}

Abayeh, O. J. (1996). An Analytical Study of the Factors Influencing Examination Malpractice in Post Primary institution. Paper Presented to WAEC Monthly Seminar, 1996.

Adamu, H. (1998). Indiscipline in Nigerian Institutions: Causes, Effects and Solutions. In A. O. Ehiozuwa (Ed.), Etiology Effect and Control of Malignancies in Nigerian Education (EEC OFMINE) (pp. 13-22). Zaria: CPSE Publishers.

Adeyemi, T. O. (2010). Examination Malpractices among Secondary School Students in the Ondo State, Nigeria: Perceived Causes and Possible Solutions. Journal of Education Administration and Policy Studies, 2, 48-55.

Afolabi, O. A. (2010). Opening Address by Permanent Secretary, Prof O.A. Afolabi, Federal Ministry of Education at the National Examination Summit Held at the National Universities Commission (NUC), Abuja, 24 May 2010.

Ammani, A. A. (2011). Examination Malpractice: The Bane of the Nigerian Education System. http://www.gamji.com

Anane, E., \& Asamoah-Gyimah, K. (2014). Assessment in Education. Unpublished, Cape Coast: University Press.

Azuru, V. A. (2009). Beyond Cognitive Assessment: Mechanics for Reducing System-General Causes of Examination Malpractices. A Paper Presented at the Annual Conference of Association for Education Assessment in Africa, Yaoundé Cameroon, 24-28 August 2009.

Badejo, A. O., \& Gandonu, M. B. (2010). Predisposing Factors towards Examination Malpractice among Students in Lagos Universities: Implications for Counselling. Edo Journal of Counselling, 3, 197-209. https://doi.org/10.4314/ejc.v3i2.63601

Bartlett, J. E., Kotrlik, J. W., \& Higgins, C. C. (2001). Organizational Research: Determining Appropriate Sample Size in Survey Research. Information Technology, Learning, and Performance Journal, 19, 43-50.

Chief Examiner's Report (2019). Release of Provisional Results for the Basic Education Certificate Examination (BECE) for School Candidates. Retrieved on 24/02/2020 from info@waecgh.org

Crown, D. F., \& Spiller, M. S. (1998). Learning from the Literature on Collegiate Cheating: A Review of Empirical Research. Journal of Business Ethics, 17, 683-700.

Erakhumen, J. (2006). Introduction to Curriculum Research and Development. London: Heinemann.

Fasasi, Y. A. (2006). Quality Assurance: A Practical Solution to Examination Malpractices in Nigerian Secondary Schools. International Journal of Africa and African American Studies, 5, 15-21.

Fayombo, G. A. (2004). Factors Influencing Examination among Nigeria Secondary Schools Student. A Paper Presented at the First National Conference of Institute of Education O.O.U, Agoiwoye, 12-15 January 2004, 160-167, Federal Ministry of Education, Science and Technology (1985). A Handbook on Continuous Assessment. Ibadan, Nigeria: Heinemann Education Books.

Genereux, R. L., \& McLeod, B. A. (1995). Circumstances Surrounding Cheating: A Questionnaire Study of College Students. Journal of Research in Higher Education, 36, 687-704. https://doi.org/10.1007/BF02208251

Mulandu, E. (2011). Cheating in Leaving School Certificate Examinations: The Case of Zambian Schools. Johannesburg: St Augustine College of South Africa. 
Ngechu, M. (2004). Understanding the Research Process and Methods. An Introduction to Research Methods.

Nwadiani, M. (2005). Curbing Examination Malpractice in the Nigerian Educational System. A Paper Presented at the First Annual Conference of the Faculty of Education, Ambrose Alli University, Ekpoma, 10-12 November 2005.

Ogonor, B. O., \& Badmus, M. M. (2006). Reflective Teaching Practice among Student Teachers: The Case in a Tertiary Institution in Nigeria. Australian Journal of Teacher Education, 31, Article No. 2. https://doi.org/10.14221/ajte.2006v31n2.2

Onuka, A. O. U. (2011). Distance Learner's Time Management. Croatia: InTech Publishers.

Roig, M., \& Ballew, C. (1994). Attitudes toward Cheating of Self and Others by College Students and Professors. The Psychological Records, 44, 3-12.

Ruwa, M. (1997). Examination Malpractices: A Case Study of the University of Maiduguri. Maiduguri Journal of Educational Studies, 3, 197-208.

Sommers, C., \& Satel, S. (2005). One Nation under Therapy. New York, NY: St. Martin's Press.

The Ghanaian Times (2011). Examination Malpractices Undermine Credibility of Education Systems. Speech of President Evans Atta Mills on WAEC's 59th Annual General Meeting, Accra, 22 March 2011, 14.

Uwadiae, I. J. (1997) School Factors as Determinants of Examination Malpractice in the Senior Secondary School Mathematics Examination in Nigeria. Unpublished Ph.D Thesis, Ibadan: University of Ibadan.

West African Examinations Council (WAEC) (2003). Student's Tricks in Examination. Lagos: West African Examinations Council.

West African Examinations Council (WAEC) (2009). Registrar's Annual Report to Council for the Period April 1, 2008 To March 31, 2009. Lagos: West African Examinations Council.

Whitley, B. E. (1998). Factors Associated with Cheating among College Students: A Review. Research in Higher Education, 39, 235-274.

https://doi.org/10.1023/A:1018724900565

Wilayat, M. (2009). Examination Malpractices: Causes of Examination Malpractices/Unfair Means. I.E.R., Peshawar: University of Peshwar.

Yakubu, L. O. (1998). Various Tricks Adopted by Students in Perpetuating Examination Malpractice in Tertiary Institutions: A Case Study of Undo State College of Education. Ikere-Ekiti. 